\title{
Translation and adaptation into Brazilian Portuguese of the Obsessional Beliefs Questionnaire (OBQ-44)
}

\author{
Tradução e adaptação para o português do Brasil \\ do Obsessional Beliefs Questionnaire (OBQ-44)
}

Cristiane Flôres Bortoncello, ${ }^{1}$ Analise Vivan, ${ }^{2}$ Juliana Braga Gomes, ${ }^{1}$ Aristides Volpato Cordioli ${ }^{3}$

\begin{abstract}
Introduction: The Obsessional Beliefs Questionnaire (OBQ-44) is a self-administered instrument comprised of 44 items, designed to assess the beliefs of patients with obsessive compulsive disorder (OCD). The objective of this study was to describe the process of translation and adaption of the questionnaire into Brazilian Portuguese.
\end{abstract}

Method: For the translation and adaptation of the OBQ-44, we first obtained authorization from the authors of the original scale to use the instrument. Subsequently, the scale was independently translated from English into Brazilian Portuguese by two health professionals with proficiency in English. Following comparison of the two translations, a preliminary version was obtained and tried out on a sample of 20 patients with a primary diagnosis of OCD. This pretest aimed to assess the patients' understanding of the items and to make any necessary language adaptations. Then, the scale was independently back-translated by two psychiatrists, also with proficiency in English. Following comparison of the two back-translations, a final version in English was developed; this version was evaluated and approved by the authors of the original instrument.

Results: The Brazilian Portuguese version of the OBQ-44, after the process of translation and adaptation here described, showed to be of easy interpretation by patients with different educational levels. The instrument can therefore be used to assess patients from different Brazilian socioeconomic contexts.

Conclusion: OBQ-44 is a self-administered instrument of easy application. Therefore, it can be useful in the identification of dysfunctional beliefs in OCD patients, contributing toward a better understanding of the role played by such beliefs in the onset and maintenance of the disorder.

Keywords: Obsessive-compulsive disorder, scales, translating.

\begin{abstract}
Resumo
Introdução: O Obsessional Beliefs Questionnaire (OBQ-44) é um instrumento autorrespondido composto por 44 itens que avaliam as crenças de pacientes com transtorno obsessivo-compulsivo (TOC). O objetivo do presente estudo foi descrever o processo de tradução e adaptação da referida escala para o português do Brasil.
\end{abstract}

Método: Para o processo de tradução e adaptação do OBQ-44, primeiramente foi obtida licença de uso da escala junto aos autores do instrumento original. Em seguida, a escala foi traduzida de inglês para português brasileiro de forma independente por dois profissionais de saúde com fluência em inglês. Comparando-se as duas escalas traduzidas, obteve-se uma versão preliminar, que foi aplicada a uma amostra de 20 pacientes com diagnóstico principal de TOC, visando observar sua compreensão e realizar adaptações de linguagem. A seguir, a escala foi retrotraduzida de forma independente por dois psiquiatras, também fluentes na língua inglesa. Comparadas as duas retrotraduções, gerou-se uma versão final em língua inglesa; esta versão foi avaliada e aprovada pelos autores do instrumento original.

Resultados: A versão em português do Brasil do OBQ-44, após sua tradução e adaptação, demonstrou ser de fácil compreensão por parte de pacientes de diferentes níveis educacionais. Portanto, a escala pode ser utilizada em pacientes das diversas classes econômicas e sociais que caracterizam o Brasil.

Conclusão: O OBQ-44, por ser um instrumento autoaplicável e de fácil compreensão, pode ser útil na identificação de crenças disfuncionais em pacientes com TOC, auxiliando na compreensão do papel dessas crenças na origem e manutenção do transtorno. Descritores: Transtorno obsessivo-compulsivo, escalas, tradução (processo).

\footnotetext{
${ }^{1}$ Mestre em Ciências Médicas: Psiquiatria, Universidade Federal do Rio Grande do Sul (UFRGS), Porto Alegre, RS, Brazil. ${ }^{2}$ Doutoranda em Ciências Médicas: Psiquiatria, UFRGS. ${ }^{3}$ Doutor. Professor associado, Departamento de Psiquiatria e Medicina Legal, UFRGS.

Submitted Dec 17 2010, accepted for publication Jun 13 2011. No conflicts of interest declared concerning the publication of this article.

Suggested citation: Bortoncello CF, Vivan A, Gomes JB, Cordioli AV. Translation and adaptation into Brazilian Portuguese of the Obsessional Beliefs Questionnaire (OBQ-44). Trends Psychiatry Psychother. 2012;34(1):31-7.
} 


\section{Introduction}

Theobsessive-compulsive disorder(OCD) is characterized by the presence of intrusive thoughts, images, or impulses (obsessions) and by repetitive behaviors (compulsions) performed with the aim of reducing discomfort or prevent the occurrence of feared outcomes. ${ }^{1}$

Although OCD is a widely studied disease, little is known about its etiology. Recent theories have proposed an integrative hypothesis, in which neurobiological (including genetic), psychological, and environmental factors are all considered to be involved in the onset of the disorder. Among psychological factors, behavioral and cognitive theories have tried to provide explanations about the origin and maintenance of OCD. ${ }^{2}$

Investigators have been working on the development of cognitive models of OCD. ${ }^{3-9}$ In spite of some variations, there is a consensus about the essential components of a cognitive model: 1) normality of intrusions: normal and pathological intrusive thoughts are two parts of a continuum; 2) distorted appraisal of intrusions: the central problem is a faulty evaluation of unwanted intrusive thoughts or obsessions; 3) neutralization and avoidance behavior: neutralization strategies increase the intensity of obsessions, and avoidance behaviors reinforce the faulty appraisal of intrusive thoughts; 4) dysfunctional beliefs: the tendency to form faulty appraisals of obsessions is a result of underlying dysfunctional beliefs that involve threat, danger, responsibility, uncertainty, need to control, and perfectionism. ${ }^{10}$

Field research studies have been conducted to assess the importance of dysfunctional beliefs in the onset and maintenance of OCD symptoms, and several instruments have been developed to assess such beliefs. In particular, the Obsessive Compulsive Cognitions Working Group (OCCWG), in 1997, ${ }^{11}$ studied 16 instruments in an attempt to develop one single questionnaire to assess different domains of beliefs that contribute to the development and maintenance of obsessivecompulsive symptoms. The following instruments were among the OCCWG selection: Irrational Beliefs Regarding Obsessions, ${ }^{12}$ Multidimensional Perfectionism Scale, ${ }^{13}$ Lucky Beliefs Questionnaire, ${ }^{14}$ Guilt Inventory, ${ }^{15}$ Responsibility Questionnaire, ${ }^{16}$ Thought-Action Fusion Scale, ${ }^{17}$ and other unpublished instruments. ${ }^{11}$ The difficulty associated with these early instruments was that that they assessed each belief independently, and none of them aimed to perform a comprehensive evaluation of OCD-related dysfunctional beliefs. In addition, the instruments currently available present an overlap of measures, have not been subjected to psychometric validation, and show a lack of consensus regarding whether the cognitive contents of each instrument are specific of OCD, and whether they were indeed important for the disorder.

In one of the attempts to consolidate the findings available about the most frequent beliefs in OCD, the OCCWG developed and validated the Obsessional Beliefs Questionnaire (OBQ), an instrument that can be considered to represent a consensus among investigators devoted to the study of cognitive models of OCD. ${ }^{18}$ Initially, the OBQ comprised 129 items $^{19}$; it was subsequently reduced to 87 items, $^{20}$ and the latest version includes 44 items (OBQ-44)..$^{21}$

The OBQ-44 presents 44 self-report items divided into three subscales that represent three domains of dysfunctional beliefs: 1 ) responsibility and threat estimation (items 1, 5, 6, 8, 15, 16, 17, 19, 22, 23, $29,33,34,36,39,41) ; 2$ ) importance and control of thoughts (items 7, 13, 21, 24, 27, 28, 30, 32, 35, 38, 42, 44); and 3) perfectionism/certainty (items 2, 3, 4, $9,10,11,12,14,18,20,25,26,31,37,40,43) .^{21}$ Items are graded using a Likert scale ranging from $1=$ totally disagree to $7=$ totally agree. ${ }^{21}$ The OBQ has been translated and validated in different countries, ${ }^{21-25}$ and it has been widely used to assess beliefs in OCD patients. ${ }^{22}$

The discriminant and convergent validity of the OBQ have been consistently shown to be satisfactory. ${ }^{19-21}$ For instance, patients with $O C D$ have shown higher scores than non-clinical controls at all OBQ subscales. In addition, significant correlations have been observed between some subscales and other measures of OCD symptoms. ${ }^{19-21,26}$ These results confirm that the OBQ44 is a useful tool in the identification of dysfunctional beliefs in OCD patients by health professionals. Moreover, because OBQ-44 is a self-administered instrument of easy application, it can be useful in both clinical and research settings.

Therefore, the objective of the present study was to describe the process of translation and adaptation of the OBQ-44 into Brazilian Portuguese.

\section{Methods}

After obtaining authorization from the authors of the original instrument, the OBQ-44 was translated from English into Brazilian Portuguese. Two translations were independently produced by a psychologist and a psychiatrist with proficiency in English who had never had contact with the scale or treated OCD patients before. Once the translation step was finished, the two versions in Brazilian Portuguese were compared, and a preliminary consensus version was produced. This preliminary version was tried out on a sample of $20 \mathrm{OCD}$ patients under treatment at Hospital de Clínicas de Porto 
Alegre, southern Brazil. The objective of this pretest was to assess the patients' understanding of the items and to make any necessary language adaptations, based on patients' suggestions to improve the instrument. The participants of the pretest were selected so as to represent different socioeconomic classes and educational levels.

During the pretest, the OBQ-44 was filled individually by each patient in the presence of the interviewer. Each interview lasted for approximately 30 minutes. First, the interviewee was asked to read the self-report statement; whenever the interviewee referred difficulties understanding a given question or word, the writing was changed until the real meaning of the item became clear to the patient. All suggestions made by the interviewees at this stage were recorded, and the necessary adjustments were made (Appendix 1). Subsequently, the scale was independently back-translated into English by two psychiatrists, also with proficiency in English who had never had contact with the original scale or treated OCD patients before. Following comparison of the two back-translations, a final version in English was developed. This version was evaluated and approved by the authors of the original instrument. Figure 1 shows the methodology used in the translation and adaptation of the OBQ-44 into Brazilian Portuguese.

The present research project and procedures were approved by the Research Ethics Committee of Hospital de Clínicas de Porto Alegre (protocol no. 07-144). All patients who agreed to participate in the study signed an informed consent form.

\section{Results}

This study adopted an intentional sampling approach. Of the 20 patients selected to participate in the pretest of the Brazilian Portuguese version of the OBQ-44, ten $(50 \%)$ were males, with a mean age of $45 \pm 16$ years (range: 20 to 65 years). Most participants had not finished higher education (75\%), and the sample included representatives of the following socioeconomic classes: A (20\%), B (35\%), C (35\%), and D (10\%).

The patients expressed doubts about the writing of some items. They asked the interviewer to provide explanations and suggested changes to improve the clarity and understanding of such items. Table 1 shows the changes incorporated into the text as a result of the pretest (Table 1). The approval of the final, backtranslated version by the authors of the original instrument attests to the validity of the Brazilian Portuguese version of the OBQ-44.

\section{Discussion}

The OBQ, in its different versions $(129,87$, and 44 items), has been continuously assessed since 2001, in terms of both the validity of results and psychometric properties. All versions have consistently showed adequate reliability and temporal stability.

In our study, three dysfunctional belief domains were assessed during the translation and adaptation of the

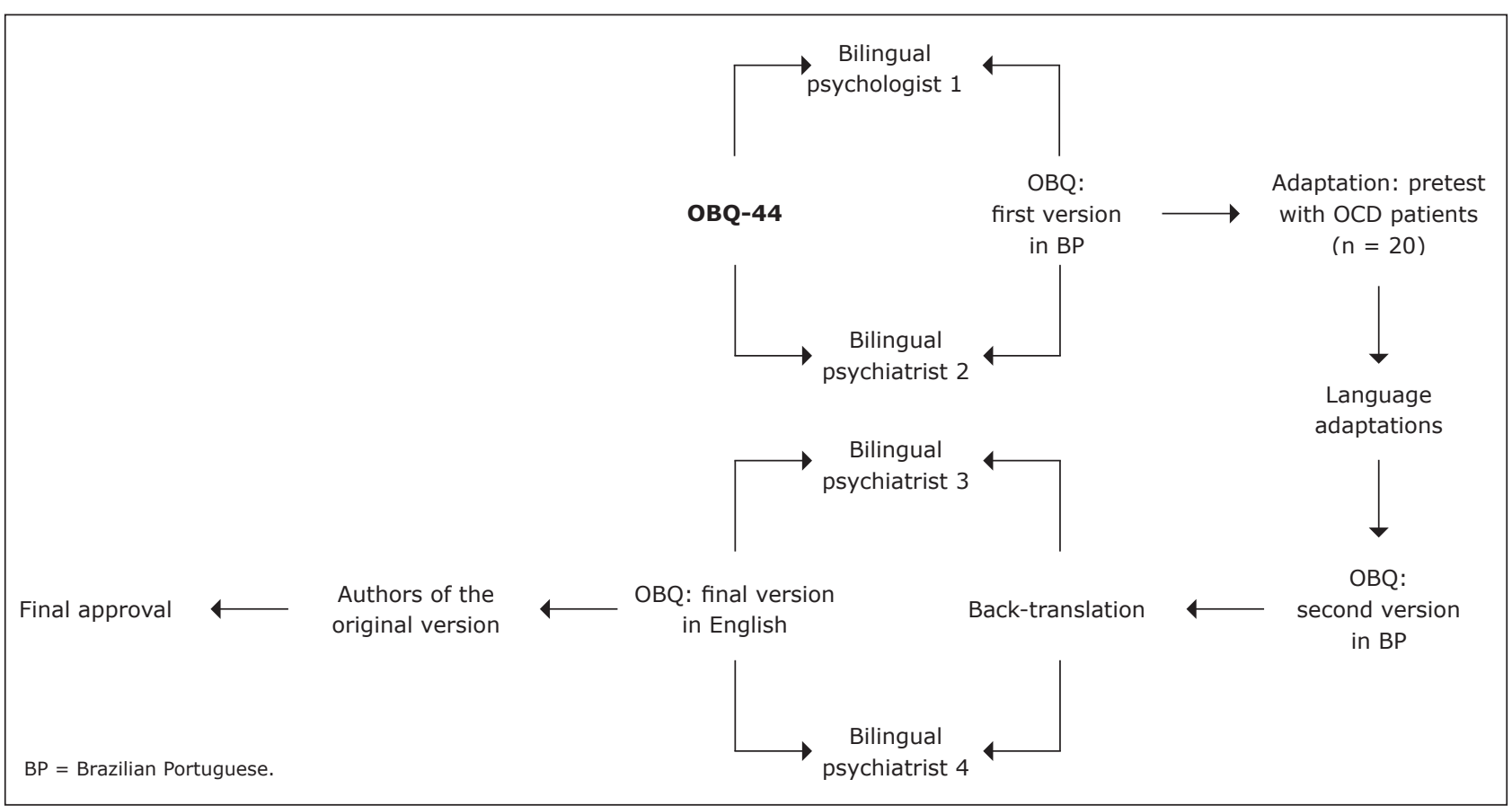

Figure 1 - Steps involved in the translation and adaptation of the OBQ-44 into Brazilian Portuguese 
Table 1 - Changes made to the Brazilian Portuguese version of the OBQ- 44 as a result of the pretest

\begin{tabular}{lll}
\hline Preliminary version & Interviewees' suggestions & Final version \\
\hline Pessoa de valor & Pessoa digna & Pessoa de valor (digna) \\
Em relação aos meus entes queridos & Sobre as pessoas importantes para mim & Sobre as pessoas importantes para mim \\
Todos os tipos de situações diárias & Todas as atividades diárias & Todas as atividades diárias \\
Precauções extras, eu tenho mais & Cuidados extras (além dos usuais), & Cuidados extras (além dos usuais), \\
probabilidade & eu tenho mais chance & eu tenho mais chance \\
Bizarros ou repulsivos & Bizarros ou revoltantes & Bizarros ou revoltantes \\
Tudo seja bem claro & Tudo seja bem claro ou compreensível & Tudo seja bem claro (compreensível) \\
Responsável pelo resultado & Responsável pelo ocorrido & Responsável pelo ocorrido \\
Pensamentos intrusivos & Pensamentos que involuntariamente & Pensamentos intrusivos (que \\
& invadem a minha mente & involuntariamente invadem a minha mente) \\
Experiências comuns & Experiências do dia a dia & Experiências comuns (do dia a dia) \\
\hline
\end{tabular}

OBQ-44 into Brazilian Portuguese. These three domains will be described below.

1) Responsibility and threat estimation. Patients believe that they can be or turn out to be the cause of harm (bad things) for themselves or for others, unless they do something to prevent or repair the harm. It is a belief in one self's power to provoke or prevent negative outcomes from happening (and in the critical need to prevent such outcomes). The most typical cognitive distortion in this domain is to believe that having any influence on an outcome means having full responsibility for that outcome. This distortion applies both to the probability of physical damage and to the harm resulting from moral fault.7,8,11,16 Overestimating the probability or severity of harm or danger is certainly the most common belief in patients with washing and checking rituals. It has two basic components: overestimation of the probability that a catastrophic event will happen and/or of the severity of its impact. A highly unlikely but high-impact event will probably cause more suffering than a more likely but low-impact event. Suffering is also influenced by the impaired evaluation of the patient's ability to deal with feared events. In a sense, one could suggest that threat overestimation overlaps with the excess of responsibility in these patients. ${ }^{11,27}$

2) Importance and control of thoughts. In this belief, the mere presence of a thought is considered to be suggestive of its importance, and the patient beliefs he/she has the power to provoke or avoid future negative events by engaging in rituals. ${ }^{5,6,11}$ This domain also includes the socalled thought-action fusion. ${ }^{17}$ One of the main dysfunctions in OCD are the presuppositions made by patients about the contents of thoughts or images that intrude their minds. One of such dysfunctions is the tendency to overestimate the importance of having full control over intrusive thoughts, images, and impulses, and the belief that such control is both possible and desirable. . $^{3,11,28-30}$

3) Perfectionism/certainty. Perfectionism is the tendency to believe that there is a perfect solution for each problem, that doing something perfect (flawless) is not only possible, but necessary, and that even small mistakes will have serious consequences. Patients' self-imposed goals are not only unrealistic, but often unreachable. ${ }^{11,16,31}$ OCD patients knowingly have greater difficulties making decisions, seem to be more cautious, keep requesting the same information, need to be repeatedly reassured, and also have many doubts about whether their decisions were right or wrong. Difficulties making decisions result from their need for certainty. ${ }^{11,32}$

Semantic equivalence analysis involves the ability to transfer conceptual meaning from the original instrument to the translated text and to achieve a similar effect on respondents from both cultures. The adaptation process should therefore combine literal translation of words and sentences from one language to the other and also a careful fine-tuning process that takes into consideration the cultural context and life style of the target population. ${ }^{33}$

Throughout the OBQ-44 cross-cultural adaptation process, we aimed for equivalence between the original scale and the translated scale. In order to guarantee that this goal would be met, a previously trained health professional applied the translated instrument to a small group of patients, with a focus on patient understanding. All participants of the pretest faced some degree of difficulty understanding selected items, which determined the replacement of some words and expressions with others more widely known among people with different educational levels. The final evaluation and approval of the back-translation, after the language adjustments, confirmed that our methodology was appropriate.

The Brazilian Portuguese version of the OBQ-44 showed to be of easy interpretation by OCD patients with different educational levels and from different Brazilian socioeconomic contexts. Moreover, OBQ-44 is useful to the investigation of phenomena that have so far been assessed only subjectively in Brazilian OCD patients, thus contributing to advance research and knowledge about OCD. The OBQ-44 is therefore an important resource for the study of dysfunctional beliefs that underlie obsessivecompulsive symptoms, whose role in the onset and maintenance of the disorder remains to be explained. 
In sum, the translation and adaptation of the OBQ44 into Brazilian Portuguese will allow investigators and health professionals to better understand the dysfunctional beliefs commonly observed in Brazilian OCD patients. The availability of the instrument in our setting not only allows further research on the topic to be undertaken, but also allows the collection of more reliable, realistic, and safe data about our population of patients with $O C D$, both in clinical and research settings.

\section{Acknowledgements}

The authors are grateful to the health professionals Lisandra B. Soldati, Ygor Ferrão, Marcelo Basso de Sousa, and Roseli Gedanke Shavitt, and to the patients who agreed to participate in the pretest.

\section{References}

1. American Psychiatric Association. Manual diagnóstico e estatístico de transtornos mentais, $4^{a}$ edição (DSM-IV-TR). Porto Alegre: Artmed; 2002.

2. Cameron CL. Obsessive-compulsive disorder in children and adolescents. J Psychiatr Ment Health Nurs. 2007;14:696-704.

3. Clark DM, Purdon C. New perspectives for a theory of obsessions. Aust Psychol. 1993;28:161-7.

4. Freeston MH, Rhéaume J, Ladouceur R. Correcting faulty appraisals of obsessive thoughts. Behav Res Ther. 1996;13:459-70.

5. Rachmann SJ. A cognitive theory of obsessions. Behav Res Ther. 1997;35:793-802.

6. Rachmann SJ. A cognitive theory of obsessions: elaborations. Behav Res Ther. 1998;36:385-401.

7. Salkoviskis PM. Obsessive-compulsive problems: a cognitivebehavioral analysis. Behav Res Ther. 1985;23:571-83.

8. Salkoviskis PM. Cognitive-behavioral factors and the persistence of intrusive thoughts in obsessional problems. Behav Res Ther. 1989;27:677-82.

9. Van Oppen P, Arntz A. Cognitive therapy for obsessivecompulsive disorder. Behav Res Ther. 1994;32:79-88.

10. Clark DA. Cognitive behavioral treatment of obsessivecompulsive disorders: a commentary. 1999;6:408-15.

11. Obsessive Compulsive Cognitions Working Group (OCCWG). Cognitive assessment of obsessive-compulsive disorder. Behav Res Ther. 1997;35:667-81.

12. Freeston $M H$, Ladouceur R, Gagnon F, Thibodeau N. Beliefs about obsessional thoughts. J Psychopathol Behav Assess. 1993;15:1-21.

13. Frost RO, Marten $P$, Lahart $C$, Rosenblate R. The dimensions of perfectionism. Cognit Ther Res. 1990;14:449-68.

14. Frost RO, Krause MS, McMahon MJ, Peppe J, Evans M, McPhee $A E$, Holden M. Compulsivity and superstitiousness. Behav Res Ther. 1993;31:423-5.

15. Kugler $\mathrm{K}$, Jones WH. On conceptualizing and assessing guilt. J Pers Soc Psychol. 1992;62:318-27.

16. Rhéaume J, Freeston MH, Dugas MJ, Letarte H, Ladouceur R. Perfectionism, responsibility and obsessive-compulsive symptoms. Behav Res Ther. 1995;33:785-94.
17. Shafran R, Thordarson DS, Rachman S. Thought action fusion in obsessive compulsive disorder. J Anxiety Disord. 1996; 5:379-91.

18. Taylor S, Kyrios M, Thordarson DS, Steketee G, Frost R. Development and validation of instruments for measuring intrusions and beliefs in obsessive-compulsive disorder. In: Frost R, Steketee G, editors. Cognitive approaches to obsessions and compulsions: theory, assessment, and treatment. New York: Pergamon; 2002. p. 117-38.

19. Obsessive Compulsive Cognitions Working Group (OCCWG). Development and initial validation of the Obsessive Beliefs Questionnaire and the Interpretation of Intrusions Inventory. Behav Res Ther. 2001;39:987-1006.

20. Obsessive Compulsive Cognitions Working Group (OCCWG). Psychometric validation of the Obsessive Belief Questionnaire and the Interpretation of Intrusions Inventory: Part I. Behav Res Ther. 2003;41:863-78.

21. Obsessive Compulsive Cognitions Working Group (OCCWG). Psychometric validation of the Obsessive Belief Questionnaire and the Interpretation of Intrusions Inventory: Part 2. Factor analyses and testing of a brief version. Behav Res Ther. 2005;43:1527-42.

22. Sica C, Coradeschi D, Sanavio E, Dorz S, Manchisi D, Novara C. A study of the psychometric properties of the Obsessive Beliefs Inventory and Interpretations of Intrusions Inventory on clinical Italian individuals. J Anxiety Disord. 2004;18:291-307.

23. Julien D, Careau Y, O'Connor KP, Bouvard M, Rhéaume J, Langlois $F$, et al. Specificity of belief domains in OCD: validation of the French version of the Obsessive Beliefs Questionnaire and a comparison across samples. J Anxiety Disord. 2008;22:1029-41.

24. Biglieri RR, Vetere YG. Adaptación argentina del cuestionario de creencias obsesivas. Interdisciplinaria. 2008;25:53-76.

25. Myers SG, Fisher PL, Wells A. Belief domains of the Obsessive Beliefs Questionnaire-44 (OBQ-44) and their specific relationship with obsessive-compulsive symptoms. J Anxiety Disord. 2008;22:475-84.

26. Tolin DF, Worhunsky P, Maltby N. Are "obsessive" beliefs specific to OCD? A comparison across anxiety disorders. Behav Res Ther. 2006;44:469-80.

27. Macfall ME, Wollersheim JP. Obsessive-compulsive neurosis: a cognitive-behavioral formulation and approach to treatment. Cognit Ther Res. 1979;3:333-48.

28. Wells A, Matthews G. Attention and emotion: a clinical perspective. Hove: Erlbaum; 1994.

29. Wells A. Cognitive therapy of anxiety disorders: a practice manual and conceptual guide. Chichester: Wiley; 1997.

30. Wells A. Emotional disorders and metacognition: innovative cognitive therapy. Chichester: Wiley; 2000.

31. Frost RO, Steketee G. Perfectionism in obsessive-compulsive disorder patients. Behav Res Ther. 1997;35:291-6.

32. Carr AT. Compulsive neurosis: a review of literature. Psychol Bull. 1974;81:311-8.

33. Reichenheim EM, Moraes CL. Operacionalização de adaptação transcultural de instrumentos de aferição usados em epidemiologia. Rev Saude Publica. 2007;41:665-73.

\section{Correspondence:}

Cristiane Flôres Bortoncello

Rua Cecília Meirelles, 442

92025-010 - Canoas, RS - Brazil

Tel.: +55 (51) 3032.3342 ou +55 (51) 9739.8544

E-mail: cris.bortoncello@terra.com.br 


\title{
Appendix 1 \\ Brazilian Portuguese version of the Obsessional Beliefs Questionnaire (OBQ-44) \\ OBQ-44
}

Autoria: Obsessive Compulsive Cognitions Working Group (OCCWG)

Tradução e adaptação: Cristiane Flôres Bortoncello e Aristides Volpato Cordioli

Nome:

Data da aplicação:

\begin{abstract}
Este inventário lista diferentes atitudes ou crenças que as pessoas algumas vezes apresentam. Leia cada afirmativa cuidadosamente e decida o quanto você concorda ou discorda em relação a ela. Para cada uma das alternativas, escolha o número correspondente à resposta que melhor descreve como você pensa. Pelo fato das pessoas serem diferentes, não há respostas certas ou erradas. Para decidir se uma determinada afirmativa é típica de sua maneira de ver as coisas, simplesmente tenha em mente o que você é na maior parte do tempo.

12

Discordo totalmente

2

Discordo moderadamente

3

Discordo um pouco

4

Nem concordo nem discordo

5

Concordo um pouco

6

Concordo moderadamente

7

Concordo totalmente
\end{abstract}

IMPORTANTE: Ao atribuir suas notas, tente evitar o ponto médio da escala (4), indicando, de preferência se você usualmente discorda ou concorda com as afirmativas sobre suas próprias crenças e atitudes.

1. Eu frequentemente penso que as coisas ao meu redor são perigosas.

2. Se eu não tiver absoluta certeza de alguma coisa, com certeza eu vou errar.

3. As coisas deveriam ser perfeitas de acordo com as minhas próprias normas/regras.

4. A fim de ser uma pessoa de valor (digna), eu devo ser perfeito em tudo que faço.

5. Quando eu percebo que tenho chance, eu devo agir para evitar que coisas ruins aconteçam.

6. Mesmo que algo ruim tenha pouca probabilidade de ocorrer, devo tentar prevenir a qualquer custo.

7. Para mim, ter vontade de fazer algo ruim é o mesmo que fazê-lo.

8. Se eu não agir quando sentir o perigo, serei responsável por quaisquer consequências.

9. Se eu não puder fazer algo perfeito, eu não deveria fazer nada.

10. Eu devo dar o máximo de mim o tempo todo.

11. É muito importante para mim considerar todas as alternativas possíveis de uma situação.

12. Mesmo tendo pequenos erros, significa que o trabalho não está completo.

13. Se eu tiver pensamentos ou impulsos agressivos sobre as pessoas importantes para mim, isto significa que, secretamente, eu quero machucá-las.

14. Devo sempre ter certeza das minhas decisões.

15. Em todas as atividades diárias, falhar em prevenir os danos é tão ruim quanto provocá-los.

16. Evitar problemas graves (por exemplo, doença ou acidentes) exige constante esforço da minha parte.

17. Para mim, não prevenir dano é tão ruim quanto causá-lo.

18. Eu deveria ficar triste se cometer um erro.

19. Eu devo ter certeza que os outros estejam protegidos de quaisquer consequências negativas das minhas decisões ou atos.

20. Para mim, as coisas não estão corretas se não estiverem perfeitas.

21. Ter pensamentos horríveis significa que eu sou uma pessoa má. $\begin{array}{lllllll}1 & 2 & 3 & 4 & 5 & 6 & 7\end{array}$

$\begin{array}{lllllll}1 & 2 & 3 & 4 & 5 & 6 & 7\end{array}$

$\begin{array}{lllllll}1 & 2 & 3 & 4 & 5 & 6 & 7\end{array}$

$\begin{array}{llllllll}1 & 2 & 3 & 4 & 5 & 6 & 7\end{array}$

$\begin{array}{lllllll}1 & 2 & 3 & 4 & 5 & 6 & 7\end{array}$

$\begin{array}{lllllll}1 & 2 & 3 & 4 & 5 & 6 & 7\end{array}$

$\begin{array}{lllllll}1 & 2 & 3 & 4 & 5 & 6 & 7\end{array}$

$\begin{array}{lllllll}1 & 2 & 3 & 4 & 5 & 6 & 7\end{array}$

$\begin{array}{lllllll}1 & 2 & 3 & 4 & 5 & 6 & 7\end{array}$

$\begin{array}{lllllll}1 & 2 & 3 & 4 & 5 & 6 & 7\end{array}$

$\begin{array}{lllllll}1 & 2 & 3 & 4 & 5 & 6 & 7\end{array}$

$\begin{array}{lllllll}1 & 2 & 3 & 4 & 5 & 6 & 7\end{array}$

$\begin{array}{lllllll}1 & 2 & 3 & 4 & 5 & 6 & 7\end{array}$

$\begin{array}{lllllll}1 & 2 & 3 & 4 & 5 & 6 & 7\end{array}$

$\begin{array}{lllllll}1 & 2 & 3 & 4 & 5 & 6 & 7\end{array}$

$\begin{array}{lllllll}1 & 2 & 3 & 4 & 5 & 6 & 7\end{array}$

$\begin{array}{lllllll}1 & 2 & 3 & 4 & 5 & 6 & 7\end{array}$

$\begin{array}{lllllll}1 & 2 & 3 & 4 & 5 & 6 & 7\end{array}$

$\begin{array}{lllllll}1 & 2 & 3 & 4 & 5 & 6 & 7\end{array}$

$\begin{array}{lllllll}1 & 2 & 3 & 4 & 5 & 6 & 7\end{array}$

$\begin{array}{lllllll}1 & 2 & 3 & 4 & 5 & 6 & 7\end{array}$ 
22. Se eu não tomar cuidados extras (além dos usuais), eu tenho mais chance do que os outros de sofrer ou causar um sério acidente.

23. Para eu me sentir seguro, tenho que estar tão preparado quanto for possível para qualquer coisa que possa dar errado.

24. Eu não deveria ter pensamentos bizarros ou revoltantes.

25. Para mim, cometer um erro é tão ruim quanto falhar totalmente.

26. É essencial que tudo seja bem claro (compreensível), mesmo nos mínimos detalhes.

27. Ter pensamentos pecaminosos é tão ruim quanto cometê-los.

$\begin{array}{lllllll}1 & 2 & 3 & 4 & 5 & 6 & 7\end{array}$

$\begin{array}{lllllll}1 & 2 & 3 & 4 & 5 & 6 & 7\end{array}$

$\begin{array}{lllllll}1 & 2 & 3 & 4 & 5 & 6 & 7\end{array}$

$\begin{array}{lllllll}1 & 2 & 3 & 4 & 5 & 6 & 7\end{array}$

$\begin{array}{lllllll}1 & 2 & 3 & 4 & 5 & 6 & 7\end{array}$

$\begin{array}{lllllll}1 & 2 & 3 & 4 & 5 & 6 & 7\end{array}$

$\begin{array}{lllllll}1 & 2 & 3 & 4 & 5 & 6 & 7\end{array}$

$\begin{array}{lllllll}1 & 2 & 3 & 4 & 5 & 6 & 7\end{array}$

$\begin{array}{lllllll}1 & 2 & 3 & 4 & 5 & 6 & 7\end{array}$

$\begin{array}{lllllll}1 & 2 & 3 & 4 & 5 & 6 & 7\end{array}$

$\begin{array}{lllllll}1 & 2 & 3 & 4 & 5 & 6 & 7\end{array}$

$\begin{array}{lllllll}1 & 2 & 3 & 4 & 5 & 6 & 7\end{array}$

$\begin{array}{lllllll}1 & 2 & 3 & 4 & 5 & 6 & 7\end{array}$

$\begin{array}{lllllll}1 & 2 & 3 & 4 & 5 & 6 & 7\end{array}$

$\begin{array}{lllllll}1 & 2 & 3 & 4 & 5 & 6 & 7\end{array}$

$\begin{array}{lllllll}1 & 2 & 3 & 4 & 5 & 6 & 7\end{array}$

$\begin{array}{lllllll}1 & 2 & 3 & 4 & 5 & 6 & 7\end{array}$

$\begin{array}{lllllll}1 & 2 & 3 & 4 & 5 & 6 & 7\end{array}$

$\begin{array}{lllllll}1 & 2 & 3 & 4 & 5 & 6 & 7\end{array}$

$\begin{array}{lllllll}1 & 2 & 3 & 4 & 5 & 6 & 7\end{array}$

$\begin{array}{lllllll}1 & 2 & 3 & 4 & 5 & 6 & 7\end{array}$

$\begin{array}{lllllll}1 & 2 & 3 & 4 & 5 & 6 & 7\end{array}$

$\begin{array}{lllllll}1 & 2 & 3 & 4 & 5 & 6 & 7\end{array}$

44. Se eu não controlar meus pensamentos, eu serei punido. 